\title{
Editorial
}

\section{Advances in Pediatric Renal Transplantation}

\author{
Vikas R. Dharnidharka ${ }^{*}$,
}

\begin{abstract}
Division of Pediatric Nephrology, Washington University School of Medicine and St. Louis Children's Hospital, Saint Louis, Missouri, USA
\end{abstract}

The science of kidney transplantation in children has advanced remarkably in the last 40 years $[1,2]$. As kidney transplants in adult recipients were becoming more common with improving short- and long-term outcomes, results in children were lagging behind. This lag was attributed to multiple factors: greater surgical and technical problems in small children, different metabolism for needed drugs, lack of actionable scientific data, and studies with inadequate sample sizes to make definitive research conclusions, among others.

Thankfully, many of these problems were overcome by teams of transplant professionals that showed unwavering dedication to their pediatric patients. In this issue, Dr. Jodi Smith provides details of the tremendous improvements in patient and graft survival achieved over the recent decades $[3,4]$. She also highlights the current challenges in further improving short- and long-term survival. Many of the medical issues that make children different from adult recipients are covered in a recent review [1]. Some selected issues are now explored in greater depth in this Supplement.

Children's immune systems have unique challenges in dealing with opportunistic infections when under extrinsic immunosuppression, especially with newer more potent immunosuppressive drugs [5]. They have often not experienced a primary infection from opportunistic microbes prior to transplantation, and therefore have developed no primary immunity against such infections should they occur after transplant. Unlike with heart/liver/lung transplantation, size matching is not necessary in kidney transplantation. Size matching is in fact rarely practiced since graft thrombosis rates are much higher in smaller donor kidneys. Hence these children predominantly receive an adult kidney from a recipient (the donor paradox) who has been exposed to opportunistic viruses that have long-lived latency in that adult host. The unfortunate child now receives these viruses as passengers with the adult organ, simultaneous to cell injury from the transplant and extrinsic drugs that suppress the child's immune system. This perfect storm makes viral infections a major ongoing challenge in pediatric renal

*Address correspondence to this author at the Division of Pediatric Nephrology, Washington University School of Medicine \& St. Louis Children's Hospital, Campus Box 8116, Room NWT 10-119, 660 South Euclid Avenue, St Louis, MO 63110, USA; Tel: 314-286-1574;

Fax: 314-286-2351; E-mail: Dharnidharka_V@kids.wustl.edu

${ }^{\S}$ Guest Editor transplantation [6]. Thus, in this Supplement, we focus on issues surrounding each of the three major viruses in kidney transplantation. Dr. Asha Moudgil and colleagues report their data from a multisite survey of the risk factors and outcomes after persistent Epstein-Barr viremia. Dr. Faris Hashim and colleagues provide data from an analysis of valganciclovir prophylaxis for cytomegalovirus. Drs. Elizabeth Anyaegbu and Paul Hmiel report their results with IVIG as a treatment for BK virus nephropathy. Each article also provides some background of each infection.

All the novel advances in medications and diagnostic technologies will not be maximally effective if the children have poor medication adherence. Adolescents, rather than infants, have comparatively poor long-term allograft survival (the recipient paradox), largely due to worse adherence [7, 8]. Drs. Beth Foster and Ahna Pai, who are leading a large multicenter randomized trial to improve medication adherence in adolescents with a kidney transplant, discuss the current state of knowledge and strategies to improve adherence.

Finally, adolescents practice many high-risk behaviors that are of special importance to immune suppressed kidney transplant recipients. Sexuality is an issue that patients and their pediatric caregivers rarely discuss, yet has direct impacts upon transplant recipient health. Drs. Isa Ashoor and Ryan Pasternak review the available knowledge regarding sexual healthin adolescent kidney transplant recipients.

We applaud the editor and publisher of Open Journal of Urology and Nephrology for soliciting a Supplement dedicated to Advances in Pediatric Renal Transplantation. The information provided here will be of value to urologists and nephrologists who are taking care of children with a kidney transplant or recently transitioned graduates of pediatric kidney transplant programs.

\section{REFERENCES}

[1] Dharnidharka VR, Fiorina P, Harmon WE. Kidney transplantation in children. N Engl J Med 2014; 371(6): 549-58.

[2] Shapiro R, Sarwal MM. Pediatric kidney transplantation. Pediatr Clin North Am 2010; 57(2): 393-400.

[3] Van Arendonk KJ et al. National trends over 25 years in pediatric kidney transplant outcomes. Pediatrics 2014; 133(4): 594-601.

[4] Smith JM et al. Contributions of the Transplant Registry: The 2006 Annual Report of the North American Pediatric Renal Trials and Collaborative Studies (NAPRTCS). Pediatr Transplant 2007; 11(4): 366-73. 
[5] Dharnidharka VR, Harmon WE. Management of pediatric postrenal transplantation infections. Semin Nephrol 2001; 21(5): 521-31.

[6] Dharnidharka VR, Stablein DM, Harmon WE. Post-transplant infections now exceed acute rejection as cause for hospitalization: a report of the NAPRTCS. Am J Transplant 2004; 4(3): 384-9.
[7] Foster BJ et al. Association between age and graft failure rates in young kidney transplant recipients. Transplantation 2011; 92(11): 1237-43.

[8] Van Arendonk KJ et al. Age at Graft Loss after Pediatric Kidney Transplantation: Exploring the High-Risk Age Window. Clin J Am Soc Nephrol 2013.

(C) Vikas R. Dharnidharka; Licensee Bentham Open.

This is an open access article licensed under the terms of the Creative Commons Attribution Non-Commercial License (http://creativecommons.org/licenses/by-nc/3.0/) which permits unrestricted, non-commercial use, distribution and reproduction in any medium, provided the work is properly cited. 